\title{
PENGARUH MOTIVASI BELAJAR DAN LINGKUNGAN TEMAN SEBAYA TERHADAP HASIL BELAJAR EKONOMI SISWA KELAS XI IIS SMA AYODHYA PURA SELAT TAHUN PELAJARAN 2018/2019
}

\author{
Luh Devi Pridayanti ${ }^{1}$, Luh Indrayani ${ }^{2}$, Kadek Rai Suwena ${ }^{3}$ \\ Program Studi Pendidikan Ekonomi \\ Universitas Pendidikan Ganesha \\ Singaraja, Indonesia
}

\begin{abstract}
e-mail: devipridayanti14@gmail.com¹ kadeksuwena@yahoo.co.id ${ }^{3}$
\end{abstract}

\begin{abstract}
Abstrak
Penelitian ini bertujuan untuk mengetahui pengaruh motivasi belajar, pengaruh lingkungan teman sebaya, serta pengaruh motivasi belajar dan lingkungan teman sebaya terhadap hasil belajar Ekonomi. Penelitian ini menggunakan rancangan penelitian kausal. Populasi dalam penelitian ini adalah siswa kelas XI pada SMA Ayodhya Pura Selat tahun pelajaran 2018/2019 dengan jumlah siswa sebanyak 35 siswa. Data dikumpulkan dengan, kuesioner dan dokumentasi yang dianalisis menggunakan analisis regresi linier berganda dengan menggunakan program SPSS(Statistical Product and Service Solutions) versi 16.0. Hasil penelitian menunjukkan bahwa ada pengaruh parsial yang positif dan signifikan dari motivasi belajar terhadap hasil belajar yang dilihat dari nilai t 2,136 dengan signifikansinya sebesar $0,040<0,05$ pada hasil uji t, ada pengaruh parsial yang positif dan signifikan dari lingkungan teman sebaya terhadap hasil belajar yang dilihat dari nilai t 2,430 dengan signifikansinya sebesar $0,021<0,05$ pada hasil uji t, dan ada pengaruh simultan yang positif dan signifikan dari motivasi belajar dan lingkungan teman sebaya terhadap hasil belajar, dilihat dari hasil uji $\mathrm{F}$ dimana diperoleh nilai $\mathrm{F}$ 10,077 dengan signifikansinya sebesar 0,000 lebih kecil dari 0,05.
\end{abstract}

Kata kunci : Motivasi Belajar, Lingkungan Teman Sebaya, Hasil Belajar.

\begin{abstract}
This study aims to know determine the effect of learning motivation, peer enviroment influences, and the influence of peer motivation and enviroment on economic learning outcomes. This study uses a casual research design. The population in this study were grade XI students at the Ayodhya Pura High School Selat 2018/2019 school year with a total of 35 students. Data collected by questionnaires and documentation were analyzed using multiple linear regression analysis using SPSS (Statistical Product and Service Solutions) program version 16.0. The results showed that there was a positive and significant partial effect of learning motivation on learning outcomes seen from $t$ value of 2,136 with a significance of $0,040<0,05$ in the t test results, there is a positive and significant partial effect of peers environment on learning outcomes seen from t value 2,430 with significance of 2,021 $<0,05$ on the t test results, and there is a positive and significant simultaneous influence of learning motivation and peer environment on learning outcomes, seen from the results of the $F$ test shere $F$ values of 10,077 are obtained with a significance of 0,000 less than 0,05 .
\end{abstract}

Keywords: Learning Motivation, Peer Friend Enviroment, Learning Outcomes. 


\section{PENDAHULUAN}

Pendidikan sebagai salah satu syarat seseorang bisa meraih kesuksesan dimasa mendatang. Menurut Dimyati dan Mudjiono (2006:7), pendidikan merupakan satuan tindakan yang memungkinkan terjadinya belajar dan perkembangan, pendidikan merupakan proses interaksi yang mendorong terjadinya belajar. Dengan adanya belajar terjadilah perkembangan jasmani dan mental siswa. Setiap individu dituntut berperan serta secara maksimal guna meningkatkan mutu pendidikan. Mutu pendidikan perlu diperhatikan untuk mencapai tujuan pendidikan, peningkatan mutu pendidikan dapat dilihat dari keberhasilan yang diraih oleh seorang siswa selama mengikuti kegiatan belajar mengajar. Tujuan pendidikan bisa tercapai dengan maksimal apabila peserta didik berperan aktif di dalam pembelajaran baik dari segi fisik, mental maupun dari segi emosionalnya.

Pendidikan dapat terjadi di lingkungan keluarga, lingkungan sekolah, maupun di lingkungan masyarakat. Berhasil tidaknya pencapaian tujuan pendidikan banyak ditentukan dari proses belajar yang dialami oleh siswa sebagai peserta didik. Pendidikan dikatakan berhasil apabila tujuan dari pendidikan dapat disampaikan kepada siswa sehingga memberikan perubahan yang lebih baik. Perubahan tidak hanya mengenai jumlah pengetahuan, melainkan juga dalam bentuk kecakapan, kebiasaan, tingkah laku, minat, dan penyesuaian diri dari segala aspek pribadi seseorang. Belajar ialah suatu proses usaha yang dilakukan seseorang untuk memperoleh suatu perubahan tingkah laku yang baru secara keseluruhan, sebagai hasil pengalamannya sendiri dalam interaksi dengan lingkungannya, Slameto (2003:3). Dalam menjalankan proses belajar, seseorang akan senantiasa berinteraksi dengan lingkungan sekitarnya yang dapat membawa pengaruh positif dan pengaruh negatif. Pengaruh positif yang diharapkan dapat mendorong siswa untuk belajar dengan baik guna mencapai tujuan pendidikannya, sedangkan pengaruh negatifnya akan menjadi penghambat bagi siswa dalam mencapai tujuan pendidikan.
Menurut Dimyati dan Mudjiono (2006:3) , hasil belajar merupakan hasil dari suatu interaksi tindak belajar dan tindak mengajar. Hasil belajar dapat dipengaruhi oleh dua faktor yaitu faktor internal dan faktor eksternal. Dimyati dan Mudjiono (2006:237), menyatakan, terdapat 12 faktor internal dan 5 faktor eksternal yang mempengaruhi hasil belajar. Faktor internal adalah faktor yang berasal dari dalam diri siswa dan faktor eksternal adalah faktor yang berasal dari luar diri siswa. Faktor Internal yang menentukan pencapaian hasil belajar yaitu, sikap terhadap belajar, motivasi belajar, konsentrasi belajar, mengolah bahan belajar, menyimpan perolehan hasil belajar, menggali hasil belajar yang tersimpan, kemampuan berprestasi atau unjuk hasil belajar, rasa percaya diri siswa, intelegensi dan keberhasilan belajar, kebiasaan belajar, cita-cita siswa. Faktor eksternal yang mempengaruhi hasil belajar yaitu, guru sebagai pembina siswa belajar, prasarana dan sarana pembelajaran, kebijakan penilaian, kurikulum sekolah, lingkungan sosial siswa di sekolah, diantaranya teman sebaya, teman sekelas, guru, kepala sekolah serta karyawan lainnya.

Salah satu faktor internal yang mempengaruhi hasil belajar adalah motivasi. Motivasi adalah perubahan energi dalam diri (pribadi) seseorang yang ditandai dengan timbulnya perasaan dan reaksi untuk mencapai tujuan. Dalam proses pembelajaran motivasi sangat dibutuhkan untuk terjadinya percepatan dalam mencapai tujuan pendidikan dan pembelajaran secara khusus. Dimyati dan Mudjiono (2006:80) berpendapat bahwa, motivasi adalah dorongan mental yang menggerakkan dan mengarahkan perilaku manusia, termasuk perilaku belajar. Jadi motivasi itu dapat dirangsang oleh faktor dari luar tetapi motivasi itu adalah tumbuh di dalam diri seseorang. Maka dapat disimpulkan motivasi belajar adalah suatu dorongan yang berasal dari dalam diri dan dari luar diri seseorang untuk melakukan suatu pekerjaan dan mencapai tujuan.

Berdasarkan hasil observasi awal terhadap siswa kelas XI IIS serta guru mata pelajaran yang bersangkutan dapat 
ditemukan bahwa, motivasi belajar siswa kelas XI IIS rendah, hal ini ditunjukkan dari hasil belajar siswa yang dicapai masih di bawah standar Kriteria Ketuntasan Minimum (KKM). Berdasarkan wawancara yang telah dilakukan peneliti pada tanggal 12 Pebruari 2018 dengan guru mata pelajaran Ekonomi, diketahui hasil belajar siswa masih belum optimal atau belum mencapai Standar KKM yang ada. Selain itu, dalam kegiatan belajar mengajar didapati siswa kurang memperhatikan guru, kurangnya semangat siswa dalam belajar ekonomi, siswa kurang dapat memahami materi pelajaran yang dijelaskan oleh guru, kurang aktifnya siswa di dalam pembelajaran, lambatnya dalam mengerjakan tugas yang diberikan oleh guru, dan terkadang siswa acuh tak acuh terhadap tugas yang diberikan. Siswa yang memiliki motivasi yang rendah akan mengakibatkan kesulitan belajar dalam menerima materi yang disampaikan oleh guru sehingga hasil belajar menjadi tidak optimal.

Faktor eksternal yang juga mempengaruhi hasil belajar siswa adalah lingkungan teman sebaya. Lingkungan Teman Sebaya adalah suatu lingkungan yang terdiri dari orang yang bersamaan usianya,Tirtarahardja (2005:181). Menurut Slavin (2009:98), lingkungan teman sebaya adalah suatu interaksi dengan orang-orang yang mempunyai kesamaan dalam usia dan status. Dalam berinteraksi siswa lebih memilih untuk bergabung dengan orang-orang yang memiliki kesamaan pikiran, maupun hobi. Teman sebaya dapat menjadi sumber informasi yang tidak di dapatkan dari keluarga. Lingkungan teman sebaya ini terdapat di sekolah maupun di tempat tinggalnya. Pendapat lainnya dari Santrock (2007:257), kelompok teman sebaya juga menjadi suatu komunitas belajar dimana terjadi pembentukan peran dan standar sosial yang berhubungan dengan pekerjaan dan prestasi.

Pengaruh teman sebaya sebagai bentuk dukungan agar dapat menjadi lebih baik dan berprestasi. Teman sebaya mampu memberikan motivasi sekaligus suasana yang membangun apabila sedang berada di dalam kelas. Siswa lebih merasa nyaman jika belajar dan bertanya mengenai materi pelajaran ataupun tugas kepada teman sebaya karena apabila bertanya kepada guru akan muncul rasa takut tersendiri. Teman sebaya juga bisa memberikan dampak yang negatif misalnya, apabila temannya pergi ke kantin atau membolos saat sedang pembelajaran berlangsung maka siswa tersebut akan ikut membolos dengan temannya, ini dikarenakan rasa pertemanan yang tinggi terhadap teman sebaya sehingga siswa ikut melakukan hal-hal yang tidak seharusnya dilakukan.

Tiap siswa tentu memiliki keinginan supaya hasil belajarnya berhasil dengan sebaik-baiknya dan tidak ada yang mengharapkan kegagalan dalam belajar. Kegagalan akan menimbulkan kekecewaan, malas belajar, rendah diri atau bahkan dapat mempengaruhi jiwanya. Hal ini tidak dapat dibiarkan begitu saja, karena akan berdampak besar terhadap hasil belajar yang diperoleh oleh siswa dan tidak tercapainya tujuan pembelajaran. Oleh karena itu perlu adanya kerjasama baik dari pihak keluarga, masyarakat, dan sekolah untuk bersama-sama menanggulangi rendahnya motivasi belajar siswa dan lingkungan teman sebaya, sehingga sekolah mampu menghasilkan lulusan yang berkompeten.

Berdasarkan latar belakang yang telah diuraikan di atas, maka penulis tertarik untuk mengadakan penelitian dengan judul Pengaruh Motivasi Belajar dan Lingkungan Teman Sebaya terhadap Hasil Belajar Ekonomi Siswa Kelas XI IIS SMA Ayodhya Pura Selat Tahun Pelajaran 2018/2019.

\section{METODE PENELITIAN}

Penelitian ini dilakukan untuk mengetahui pengaruh motivasi belajar (X1) secara parsial terhadap hasil belajar $(Y)$, lingkungan teman sebaya $(X 2)$ secara parsial terhadap hasil belajar (Y), dan pengaruh motivasi belajar (X1) dan lingkungan teman sebaya secara simultan terhadap hasil belajar mata pelajaran Ekonomi (Y). Sehubungan dengan itu, penelitian ini termasuk penelitian kausal, dimana penelitian kausal adalah suatu penelitian yang dilakukan untuk 
menggambarkan skema pengaruh yang lebih dalam dari dua atau lebih fakta-fakta dan sifat-sifat objek yang diteliti.

Populasi dalam penelitian ini adalah siswa kelas XI pada SMA Ayodhya Pura Selat tahun pelajaran 2018/2019 dengan jumlah siswa sebanyak 35 siswa. Menurut Arikunto (2006:107) apabila subjek kurang dari 100 orang lebih baik diambil semua sehingga merupakan penelitian populasi. Karena dalam penelitian ini jumlah subjek penelitian dibawah 100 maka populasi penelitian juga merupakan sampel penelitian. Penelitian ini merupakan penelitian populasi karena semua populasi dijadikan sebagai objek penelitian atau sasaran penelitian.

Jenis data yang digunakan pada penelitian ini adalah data kuantitatif. Data kuantitatif yaitu data yang berhubungan dengan angka-angka, baik yang diperoleh dari hasil pengukuran maupun dari nilai suatu data yang diperoleh. Dalam penelitian ini, penggunaan data kuantitatif bertujuan untuk mengetahui pengaruh motivasi belajar dan lingkungan teman sebaya terhadap hasil belajar siswa kelas XI IIS SMA Ayodhya Pura Selat tahun pelajaran 2018/2019. Data kuantitatif dalam penelitian ini berupa hasil kuesioner penelitian, jumlah siswa, dan hasil nilai ulangan siswa.

Sumber data yang digunakan dalam penelitian ini adalah data primer dan data sekunder. Data primer yaitu data yang diperoleh dengan mengadakan pengamatan secara langsung serta melakukan dokumentasi data yang ada kaitannya dengan penelitian ini. Dalam penelitian ini data primer berupa angkaangka hasil kuesioner dari motivasi belajar dan lingkungan teman sebaya. Data sekunder yaitu sumber data penelitian yang diperoleh secara tidak langsung melalui media perantara. Dalam penelitian ini data sekunder berupa data dokumentasi dari sekolah seperti data hasil belajar berupa nilai rapor, nama dan jumlah siswa kelas XI IIS di SMA Ayodhya Pura Selat tahun pelajaran 2018/2019.

Data motivasi belajar dan lingkungan teman sebaya dikumpulkan menggunakan kuesioner / angket. Caranya dengan membagikan lembar kuesioner / angket berupa pernyataan kepada siswa untuk memperoleh data yang berhubungan dengan motivasi belajar dan lingkungan teman sebaya terhadap hasil belajar siswa kelas XI IIS SMA Ayodhya Pura Selat tahun pelajaran $2018 / 2019$. Dalam penelitian ini digunakan kuesioner tertutup yaitu kuesioner yang pertanyaannya disertai dengan pilihan jawaban yang sudah ditentukan oleh peneliti. Skala pengukuran yang digunakan dalam angket menggunakan skala bertingkat (skala likert) dengan 5 alternatif jawaban yang tersedia dalam bentuk pernyataan. Data hasil belajar siswa diperoleh dengan metode dokumentasi dimana peneliti memperoleh langsung data hasil belajar siswa dari guru mata pelajaran ekonomi kelas XI.

Instrumen penelitian adalah alat yang digunakan untuk mengumpulkan data atau informasi yang bermanfaat untuk menjawab permasalahan penelitian. Instrumen dalam penelitian ini adalah data kuesioner yang berisi daftar pertanyaan yang akan disebarkan kepada responden dalam hal ini adalah seluruh siswa kelas XI Jurusan IIS di SMA Ayodhya Pura Selat tahun pelajaran 2018/2019. Instrumen penelitian harus melalui uji validitas dan uji reliabilitas. Validitas berkenaan dengan ketepatan alat ukur terhadap konsep yang diukur, sehingga betul-betul mengukur apa yang seharusnya diukur, Sudjana dan Ibrahim (2004:117). Menurut Sugiyono (2010) uji validitas diperoleh dengan cara mengkorelasikan setiap skor butir pertanyaan dengan skor totalnya. Uji validitas instrumen dihitung menggunakan SPSS (Statistical Product and Service Solutions) versi 16.0 for windows dengan menggunakan rumus Product Moment dengan angka kasar dari Karl Pearson. Untuk menentukan valid atau tidak, maka dapat dilakukan dengan cara membandingkan antara nilai $r_{\text {hitung }}$ dan $r_{\text {tabel }}$ dengan taraf signifikan yang digunakan yaitu 5\%. Apabila $r_{\text {hitung }}>r_{\text {tabel }}$ maka instrumen dikatakan valid, sebaliknya jika $r_{\text {hitung }}<r_{\text {tabel }}$ maka instrumen dapat dikatakan tidak valid.

Reliabilitas alat ukur adalah ketepatan atau keajegan alat tersebut dalam mengukur apa yang diukur. Artinya, 
kapan pun alat ukur tersebut digunakan akan memberikan hasil ukur yang sama, Sudjana dan Ibrahim (2004:120-121). Kuesioner dikatakan reliabel jika dapat memberikan hasil relatif sama pada saat dilakukan pengukuran kembali pada objek yang berlainan pada waktu yang berbeda. Instrumen yang baik adalah instrumen yang dapat dengan ajeg memberikan data yang sesuai dengan kenyataan, Arikunto, (2006:86). Dalam penelitian, untuk menghitung reliabilitas kuesioner bentuk objektif digunakan program Statistic Product and Service Solution (SPPS) for Windows versi 16.0 dengan menggunakan rumus Alpha Cronbach. Nilai batas yang diperkenalkan untuk menilai apakah setiap variabel dapat dipercaya, handal, dan akurat dipergunakan formula koefisien Alpha Cronbach. Suatu instrumen dikatakan reliabel jika koefisien alpha lebih dari atau sama dengan 0,600. Sebaliknya, jika reliabilitas kurang dari 0,600 maka instrumen tersebut tidak reliabel.

Teknik analisis data yang digunakan dalam penelitian ini adalah regresi linear berganda. Regresi linear berganda digunakan untuk menguji pengaruh dua atau lebih variabel bebas terhadap satu variabel terikat. Bentuk persamaan dari regresi linear berganda sebagai berikut.

$\mathrm{Y}=\alpha+\beta 1 \mathrm{X} 1+\beta 2 \mathrm{X} 2$

Keterangan :

(Sugiyono 2010)

$$
\begin{array}{rlrl}
Y & = & \text { dividen pay out ratio } \\
\alpha & = & \text { konstanta } \\
\beta 1 & = & \text { koefisien regresi linear berganda } \\
& \text { variabel } X 1 \\
\beta 2 \quad= & \text { koefisien regresi linear berganda } \\
& \text { variabel } X 2 \\
X 1 & = & \text { motivasi belajar } \\
X 2 & = & \text { lingkungan teman sebaya }
\end{array}
$$

Untuk memperoleh jawaban dari rumusan masalah yang pertama dan ke dua menggunakan uji t'test, dan untuk memperoleh jawaban dari rumusan masalah yang ketiga menggunakan uji F'test. Sebelum dilakukan analisis data terlebih dahulu dilakukan uji asumsi klasik untuk mengetahui regresi layak atau tidaknya data ini diteliti.
Sebelum analisis data, terlebih dahulu dilakukan uji prasyarat untuk mengetahui apakah model regresi layak untuk diteliti. Uji asumsi klasik adalah persyaratan analisis yang harus dipenuhi pada analisis regresi linier berganda. Menurut Ghozali (2012) terdapat empat uji asumsi klasik yang harus dilaksanakan, yaitu sebagai berikut. Uji asumsi klasik yang pertama adalah uji normalitas.

Uji normalitas bertujuan apakah dalam model regresi variabel terikat dan variabel bebas mempunyai kontribusi atau tidak. Model regresi yang baik adalah data distribusi normal atau mendekati normal. Dalam penelitian ini, uji normalitas menggunakan grafik normal probability $p$ plot dan Kolmogorov-smirnoc (1-sampel $\mathrm{K}$-S) bila $p$-value $>0.05$, maka data dinyatakan berdistribusi normal. Uji asumsi klasik yang kedua adalah uji multikolinearitas.

Uji multikolinearitas bertujuan untuk menguji apakah suatu model regresi terdapat korelasi antar variabel bebas. Model regresi yang baik seharusnya tidak terjadi korelasi antar variabel bebas. Pengujian multikolinearitas dilihat dari besaran VIF (Variance Inflation Factor) dan tolerance. Tolerance mengukur variabel bebas yang terpilih yang tidak dijelaskan oleh variabel bebas lainnya. Bila nilai VIF $<10$ dan tolerance $>0,10$ maka model regresi yang digunakan terbebas dari masalah multikolinearitas. Uji asumsi klasik yang ketiga adalah uji autokorelasi.

uji autokorelasi bertujuan menguji apakah dalam model regresi ada korelasi antara kesalahan pengganggu pada periode-t dengan kesalahan pengganggu pada periode t-1 (sebelumnya). Pengujian autokorelasi dilakukan dengan uji Durbin Watson dengan membandingkan nilai Durbin Watson hitung (d) dengan nilai Durbin Watson tabel, yaitu batas atas (du) dan batas bawah (dL). Kriteria pengujian adalah sebagai berikut. Jika $0<\mathrm{d}<\mathrm{dL}$, maka terjadi autokorelasi positif. Jika $\mathrm{dL}<\mathrm{d}<4$, maka tidak ada kepastian terjadi autokorelasi atau tidak. Jika $\mathrm{d}<\mathrm{dL}<\mathrm{d}<4$, maka terjadi autokorelasi negatif. Jika 4$\mathrm{du}<\mathrm{d}<4<\mathrm{dL}$, maka tidak ada kepastian terjadi autokorelasi atau tidak. Jika 
$\mathrm{du}<\mathrm{d}<4<\mathrm{du}$, maka tidak terjadi autokorelasi positif ataupun negatif. Uji asumsi klasik yang keempat adalah uji heteroskedastisitas.

Uji heteroskedastisitas bertujuan menguji apakah dalam model regresi terjadi ketidaksamaan varian dari residual satu pengamatan ke pengamantan yang lain". Jika varian dari residual satu pengamatan lain tetap, maka disebut homoskedastisitas dan jika berbeda disebut heteroskedastisitas.

Setelah melakukan uji asumsi klasik dan data berdistribusi normal maka akan dilanjutkan dengan uji hipotesis. Uji hipotesis yang dilakukan pertama adalah uji t. Uji $t$ digunakan untuk menguji seberapa jauh pengaruh variabel bebas yang digunakan dalam penelitian ini secara individual dalam menerangkan variabel terikat secara parsial. Analisis ini digunakan untuk mengetahui pengaruh motivasi belajar (X1) terhadap hasil belajar (Y) dan pengaruh lingkungan teman sebaya (X2) terhadap hasil belajar (Y). Dasar pengambilan keputusan digunakan dalam uji $\mathrm{t}$ adalah jika nilai probabilitas signifikansi > 0,05 maka Ho ditolak, hipotesis ditolak mempunyai arti bahwa variabel Independen (bebas) tidak berpengaruh signifikan terhadap variabel Dependen (terikat), yaitu motivasi belajar tidak berpengaruh terhadap hasil belajar dan lingkungan teman sebaya tidak berpengaruh terhadap hasil belajar. Jika nilai probabilitas signifikansi $<0,05$ maka Ho diterima, hipotesis diterima mempunyai arti bahwa variabel Independen (bebas) berpengaruh signifikan terhadap variabel Dependen (terikat), yaitu motivasi belajar berpengaruh terhadap hasil belajar dan lingkungan teman sebaya berpengaruh terhadap hasil belajar.

Setelah melakukan uji t, maka selajutnya dilakukan uji $F$. uji statistik $F$ pada dasarnya menunjukkan apakah semua variabel bebas yang dimasukkan dalam model mempunyai pengaruh secara bersama-sama terhadap variabel terikat. Analisis ini digunakan untuk menguji hipotesis ke-3 yaitu pengaruh motivasi belajar (X1) dan lingkungan teman sebaya (X2) terhadap hasil belajar (Y) ekonomi siswa kelas X IIS SMA Ayodhya Pura
Selat tahun pelajaran 2017/2018. Untuk menguji hipotesis ini digunakan statistic $F$ dengan kriteria pengambilan keputusan jika nilai signifikansi pada hasil uji $\mathrm{F}<$ 0,05, maka dengan kata lain kita dapat menerima $\mathrm{Ha}$ yang menyatakan bahwa semua variabel Independen (bebas) secara serentak dan signifikan mempengaruhi variabel Dependen (terikat), yaitu motivasi belajar dan lingkungan teman sebaya berpengaruh terhadap hasil belajar. Jika nilai signifikansi hasil uji $\mathrm{F}>0,05$ maka $\mathrm{Ho}$ diterima (koefisien regresi tidak signifikan). Ini berarti bahwa secara simultan kedua variabel Independen (bebas) tersebut tidak mempunyai pengaruh yang signifikan terhadap variabel Dependen (terikat), yaitu motivasi belajar dan lingkungan teman sebaya tidak berpengaruh terhadap hasil belajar.

\section{HASIL DAN PEMB AHASAN Hasil Penelitian}

Berdasarkan data hasil analisis data menunjukkan bahwa pengaruh motivasi belajar dan lingkungan teman sebaya terhadap hasil belajar ekonomi siswa kelas XI IIS SMA Ayodhya Pura Selat ajaran 2018/2019. Sebelum data hasil penelitian dipaparkan, terlebih dahulu akan disajikan hasil pengujian validitas, reliabilitas dan uji asumsi klasik sebagai prasyarat analisis. Sebelum melakukan analisis regresi peneliti juga melakukan uji validitas untuk mengukur tingkat kevalidan atau kesahan suatu instrument dan uji reliabilitas. Kriteria sebuah item pernyataan dikatakan valid jika nilai korelasi > korelasi tabel, dimana jumlah responden 30 orang maka nilai korelasi tabel menunjukkan angka 0.361 jika kriteria sudah dipenuhi berarti pernyataan sudah cukup valid. Hasil dari uji validitas semua variabel yang diajukan kepada 30 responden tertera pada lampiran.

Berdasarkan hasil uji validitas diatas dapat disimpulkan bahwa 21 butir soal yang mewakili nilai korelasi > 0.361 maka pernyataan soal dapat digunakan dan 6 butir soal memiliki nilai korelasi $<0.361$ maka pernyataan butir soal dihilangkan. Untuk hasil SPSS uji validitas dapat dilihat di Lampiran. Untuk menguji instrument 
penelitian ini, peneliti menggunakan program SPSS 16 sebagai alat analisisnya.

Setelah melakukan uji validitas dan uji reliabilitas data yang sudah dinyatakan berdistribusi normal, selanjutnya dilakukan uji asumsi klasik yaitu Uji Normalitas, Uji
Multikolinearitas, Uji Autokorelasi, dan Uji Heteroskedastisitas. Setelah melakukan uji asumsi dan data berdistribusi normal maka dilanjutkan dengan uji $t$ yaitu Pengaruh motivasi belajar terhadap hasil belajar siswa. Hasil output dari pengujian ini dapat dilihat pada tabel 1.

Tabel 1. Hasil Uji t Pengaruh Motivasi Belajar terhadap Hasil Belajar Siswa Coefficients $^{\text {a }}$

\begin{tabular}{|c|c|c|c|c|c|}
\hline \multirow[b]{2}{*}{ Model } & \multicolumn{2}{|c|}{$\begin{array}{l}\text { Unstandardized } \\
\text { Coefficients }\end{array}$} & \multirow{2}{*}{$\begin{array}{c}\begin{array}{c}\text { Standardized } \\
\text { Coefficients }\end{array} \\
\text { Beta } \\
\end{array}$} & \multirow[b]{2}{*}{ T } & \multirow[b]{2}{*}{ Sig. } \\
\hline & $B$ & Std. Error & & & \\
\hline (Constant) & 39.405 & 6.884 & & 5.724 & .000 \\
\hline Motivasi Belajar (X1) & .350 & .164 & .338 & 2.136 & .040 \\
\hline Lingkungan Teman sebaya & .621 & .256 & .384 & 2.430 & .021 \\
\hline
\end{tabular}

a. Dependent Variable: Hasil Belajar

Dilihat dari tabel 1 di atas, diperoleh nilai thitung sebesar 2,136 $>t_{\text {tabel }}$ sebesar 1,690 dengan nilai signifikansi 0,040 kurang dari 0,05 atau signifikansi $t$ lebih kecil dari $5 \%$ yaitu $(0,040<0,05)$ sehingga hipotesis nol ( $\mathrm{HO})$ ditolak dan hipotesis alternatif diterima $(\mathrm{Ha})$. Jadi dapat disimpulkan bahwa ada pengaruh variabel motivasi belajar terhadap hasil belajar ekonomi siswa kelas XI IIS SMA Ayodhya Pura Selat tahun pelajaran 2018/2019.

Berdasarkan hasil penelitian yang terlihat pada tabel 1 dapat kita simpulkan bahwa model regresi yang terbentuk antara motivasi belajar dan lingkungan teman sebaya terhadap hasil belajar siswa dapat dibuat persamaan regresi sebagai berikut.

$Y=39,405+0,350 X 1+0,621 X 2$

Keterangan :

$\mathrm{Y}=$ Hasil Belajar

$\mathrm{X} 1$ = Motivasi Belajar

X2 = Lingkungan Teman Sebaya

Tabel 2. Hasil Uji t Pengaruh Lingkungan Teman Sebaya terhadap Hasil Belajar Siswa Coefficients $^{\mathrm{a}}$

\begin{tabular}{|c|c|c|c|c|c|}
\hline \multirow[b]{2}{*}{ Model } & \multicolumn{2}{|c|}{$\begin{array}{c}\text { Unstandardized } \\
\text { Coefficients }\end{array}$} & \multirow{2}{*}{$\begin{array}{c}\begin{array}{c}\text { Standardized } \\
\text { Coefficients }\end{array} \\
\text { Beta }\end{array}$} & \multirow[b]{2}{*}{$t$} & \multirow[b]{2}{*}{ Sig. } \\
\hline & $B$ & Std. Error & & & \\
\hline (Constant) & 39.405 & 6.884 & & 5.724 & .000 \\
\hline Motivasi Belajar (X1) & .350 & .164 & .338 & 2.136 & .040 \\
\hline Lingkungan Teman sebaya & .621 & .256 & .384 & 2.430 & .021 \\
\hline
\end{tabular}

a. Dependent Variable: Hasil Belajar

Dilihat dari tabel 2 di atas, diperoleh nilai thitung $2,430>t_{\text {tabel }} 1,690$ atau signifikansi $\mathrm{t}$ lebih kecil dari $5 \%$ $(0,021<0,05) \quad$ sehingga dapat disimpulkan bahwa hipotesis nol $(\mathrm{H} 0)$ ditolak dan hipotesis alternatif diterima (Ha). Jadi ada pengaruh lingkungan teman sebaya terhadap hasil belajar ekonomi siswa kelas XI IIS SMA Ayodhya Pura Selat tahun pelajaran 2018/2019.

Pengujian secara simultan dilakukan untuk menunjukkan apakah variabel terikat yaitu motivasi belajar $\left(X_{1}\right)$

dan lingkungan teman sebaya $\left(X_{2}\right)$ secara bersama-sama berpengaruh positif dan signifikan terhadap hasil belajar siswa (Y). semua variabel yang diteliti tersebut diuji secara serentak dengan menggunakan uji $\mathrm{F}$ atau tabel ANOVA. Berdasarkan dari tabel 3 hasil uji hipotesis model regresi secara simultan di bawah, diperoleh nilai $F_{\text {hitung }} 10,077>$ nilai $F_{\text {tabel }} 3,28$ atau signifikansi $\mathrm{F}$ lebih kecil dari 5\% $(0,000<$ $0,05)$ sehingga dapat disimpulkan bahwa hipotesis nol $(\mathrm{HO})$ ditolak dan hipotesis alternatif diterima ( $\mathrm{Ha})$. Jadi ada pengaruh 
motivasi belajar dan lingkungan teman sebaya terhadap hasil belajar ekonomi siswa kelas XI IIS SMA Ayodhya Pura Selat tahun pelajaran 2018/2019. Untuk lebih jelas, hasil uji F Pengaruh Motivasi Belajar dan Lingkungan Teman Sebaya terhadap Hasil Belajar siswa dapat dilihat pada tabel 3 dibawah ini.

Tabel 3. Hasil Uji Hipotesis Model Regresi Secara Simultan ANOVA $^{\mathrm{b}}$

\begin{tabular}{|c|c|c|c|c|c|c|}
\hline Model & & $\begin{array}{l}\text { Sum of } \\
\text { Squares }\end{array}$ & Df & Mean Square & $\mathrm{F}$ & Sig. \\
\hline \multirow[t]{3}{*}{1} & Regression & 223.205 & 2 & 111.602 & 10.077 & $.000^{a}$ \\
\hline & Residual & 354.395 & 32 & 11.075 & & \\
\hline & Total & 577.600 & 34 & & & \\
\hline
\end{tabular}

a. Predictors: (Constant), Lingkungan Teman sebaya, Motivasi Belajar (X1)

b. Dependent Variable: Hasil Belajar

Tabel 4. Hasil Uji Koefisien Determinasi

Model Summary ${ }^{\mathrm{b}}$

\begin{tabular}{ccccc}
\hline & & \multicolumn{3}{c}{ Adjusted $\mathrm{R}$} \\
Model & $\mathrm{R}$ & R Square & Square & Std. Error of the Estimate \\
\hline 1 & $.622^{\mathrm{a}}$ & .386 & .348 & 3.328 \\
\hline
\end{tabular}

a. Predictors: (Constant), Lingkungan Teman sebaya, Motivasi Belajar (X1)

b. Dependent Variable: Hasil Belajar

Untuk mengetahui besarnya pengaruh motivasi belajar dan lingkungan teman sebaya terhadap hasil belajar siswa, dapat dilihat melalui hasil analisis koefisien determinasi (Adjusted $R$ Square).

Berdasarkan tabel ouput SPSS "Model Summary" di atas, diketahui nilai koefisien determinasi atau $\mathrm{R}$ Square adalah sebesar 0,386 atau sama dengan $38,6 \%$ yang mengandung arti bahwa motivasi belajar dan lingkungan teman sebaya secara simultan berpengaruh terhadap hasil belajar siswa. Sedangkan sisanya $(100 \%-38,6 \%=61,4 \%)$ dipengaruhi oleh variabel lain.

\section{Pembahasan}

Berdasarkan dari hasil penelitian yang dilakukan penulis, terlihat pada saat pembelajaran berlangsung terdapat siswa kurang memperhatikan guru di depan kelas saat memaparkan materi yang diajarkan. Kurangnya semangat siswa dalam belajar ekonomi, hal ini terlihat pada saat siswa diberikan pertanyaan mengenai materi yang telah disampaikan, ada beberapa siswa yang belum mengerti tetapi siswa-siswa tersebut hanya diam saja. Keterlambatan siswa dalam mengumpulkan tugas yang diberikan oleh guru dan ada saja siswa yang tidak mengumpulkan tugas yang telah diberikan. Siswa yang memiliki motivasi yang rendah akan mengakibatkan kesulitan belajar dalam menerima materi yang disampaikan oleh guru sehingga hasil belajar menjadi tidak optimal.

Hasil penelitian ini didukung oleh teori yang dikemukakan oleh Dimyati dan Mudjiono (2006) bahwa motivasi belajar mampu mempengaruhi hasil belajar siswa. Motivasi adalah dorongan mental yang menggerakkan dan mengarahkan perilaku manusia, termasuk perilaku belajar. Motivasi ini perlu diperhatikan dalam proses belajar, karena jika siswa belajar dan sudah ada motivasi maka hasil belajarnya akan lebih baik. Siswa yang menginginkan hasil belajar yang baik harus meningkatkan motivasi belajarnya terlebih dahulu.

Berdasarkan dari hasil penelitian yang dilakukan penulis, terlihat bahwa siswa lebih merasa nyaman jika belajar dan bertanya mengenai materi pelajaran ataupun tugas kepada teman sebaya, hal ini dikarenakan apabila bertanya kepada guru akan muncul rasa takut tersendiri. Siswa yang kurang memahami materi 
pelajaran yang dijelaskan oleh guru, akan bertanya mengenai materi yang telah diajarkan kepada teman sebangku. Teman sebaya juga memberikan dampak yang negatif yaitu seringnya membolos, pada saat pembelajaran berlangsung terdapat satu siswa yang keluar permisi untuk ke kamar mandi, kemudian disusul oleh siswa yang lainnya. Setelah ditelusuri ternyata mereka pergi ke kantin, bukan ke kamar mandi dan sampai pelajaran selesai mereka juga belum kembali ke kelas, hal ini terjadi dikarenakan rasa pertemanan yang tinggi terhadap teman sebaya sehingga siswa ikut melakukan hal-hal yang temannya lakukan.

Hasil penelitian ini didukung oleh teori yang dikemukakan oleh Dimyati dan Mudjiono (2006) bahwa lingkungan teman sebaya mampu mempengaruhi hasil belajar siswa. Hal ini dilihat dari lingkungan pergaulan siswa yang baik akan mampu meningkatkan hasil belajar yang diperoleh. Dan begitupun sebaliknya apabila lingkungan pergaulan siswa tidak baik maka hasil belajar yang dicapai kurang optimal.

Berdasarkan dari hasil penelitian yang dilakukan penulis, terlihat pada saat pembelajaran berlangsung didapati siswa kurang memperhatikan guru di depan kelas saat memaparkan materi yang diajarkan. Kurangnya semangat siswa dalam belajar ekonomi, hal ini terlihat pada saat siswa diberikan pertanyaan mengenai materi yang telah disampaikan, ada beberapa siswa yang belum mengerti tetapi siswa-siswa tersebut hanya diam saja. Keterlambatan siswa dalam mengumpulkan tugas yang diberikan oleh guru dan ada saja siswa yang tidak mengumpulkan tugas yang telah diberikan. Siswa yang memiliki motivasi yang rendah akan mengakibatkan kesulitan belajar dalam menerima materi yang disampaikan oleh guru sehingga hasil belajar menjadi tidak optimal.

Selain motivasi belajar, lingkungan teman sebaya juga berpengaruh terhadap hasil belajar. Berdasarkan dari hasil penelitian yang telah dilakukan, terlihat bahwa siswa lebih merasa nyaman jika belajar dan bertanya mengenai materi pelajaran ataupun tugas kepada teman sebaya, hal ini dikarenakan apabila bertanya kepada guru akan muncul rasa takut tersendiri. Siswa yang kurang memahami materi pelajaran yang dijelaskan oleh guru, akan bertanya mengenai materi yang telah diajarkan kepada teman sebangku. Teman sebaya juga memberikan dampak yang negatif yaitu seringnya membolos, pada saat pembelajaran berlangsung terdapat satu siswa yang keluar permisi untuk ke kamar mandi, kemudian disusul oleh siswa yang lainnya. Setelah ditelusuri ternyata mereka pergi ke kantin, bukan ke kamar mandi dan sampai pelajaran selesai mereka juga belum kembali ke kelas, hal ini terjadi dikarenakan rasa pertemanan yang tinggi terhadap teman sebaya sehingga siswa ikut melakukan hal-hal yang temannya lakukan.

Hasil penelitian ini didukung oleh Dimyati dan Mudjiono (2006) bahwa motivasi belajar dan lingkungan teman sebaya perlu diperhatikan dalam proses belajar mengajar, karena jika siswa belajar dan padanya sudah ada motivasi dan didukung adanya teman sebaya yang baik, maka hasil belajarnya akan meningkat. Motivasi belajar yang tinggi dan lingkungan teman sebaya yang baik akan mampu meningkatkan perolehan hasil belajar siswa.

\section{SIMPULAN DAN SARAN Simpulan}

Berdasarkan hasil penelitian danpembahasan maka dapat disimpulkan sebagai berikut. Pertama ada pengaruh motivasi belajar terhadap hasil belajar ekonomi siswa kelas XI IIS SMA Ayodhya Pura Selat Tahun Pelajaran 2018/2019. Hal ini dilihat dari nilai thitung 2,136 $>t_{\text {tabel }}$ 1,690 atau signifikansi t lebih kecil dari $5 \%$ $(0,040<0,05)$ sehingga dapat disimpulkan bahwa hipotesis nol $(\mathrm{H} 0)$ ditolak dan hipotesis alternatif diterima $(\mathrm{Ha})$.

Kedua ada pengaruh lingkungan teman sebaya terhadap hasil belajar ekonomi siswa kelas XI IIS SMA Ayodhya Pura Selat Tahun Pelajaran 2018/2019. Hal ini dilihat dari nilai thitung $2,430>t_{\text {tabel }}$ 1,690 atau signifikansi t lebih kecil dari $5 \%$ $(0,021<0,05) \quad$ sehingga dapat 
disimpulkan bahwa hipotesis nol $(\mathrm{H} 0)$ ditolak dan hipotesis alternatif diterima (Ha).

Ketiga ada pengaruh motivasi belajar dan lingkungan teman sebaya terhadap hasil belajar ekonomi siswa kelas XI IIS SMA Ayodhya Pura Selat Tahun Pelajaran 2018/2019. Hal ini dilihat dari nilai $F_{\text {hitung }} 10,077>$ nilai $F_{\text {tabel }} 3,28$ atau signifikansi $F$ lebih kecil dari $5 \%$ $(0,000<0,05) \quad$ sehingga dapat disimpulkan bahwa hipotesis nol (HO) ditolak dan hipotesis alternatif diterima (Ha).

\section{Saran}

Adapun saran yang bisa diberikan peneliti melalui hasil penelitian yang dilakukan bagi pihak-pihak yang terkait dengan penelitian ini, sebagai berikut.

Saran yang pertama bagi guru Hasil penelitian ini dapat digunakan sebagai gambaran bagi guru bahwa hasil belajar siswa dipengaruhi oleh motivasi belajar dan lingkungan teman sebaya. Guru diharapkan dapat mengarahkan perilaku dan lingkungan teman sebaya siswa. Selain itu, guru diharapkan dapat meningkatkan motivasi belajar siswa dengan cara menumbuhkan kesadaran bagi siswa agar dapat merasakan pentingnya belajar, melakukan komunikasi lebih dekat, dan menciptakan kondisi yang menyenangkan dalam pembelajaran.

Saran yang kedua bagi peneliti selanjutnya yang akan melaksanakan penelitian mengenai hasil belajar dapat menambahkan variabel bebas lainnya yang mempengaruhi hasil belajar. Tidak hanya untuk menggunakan variabel motivasi belajar dan lingkungan teman sebaya.

\section{DAFTAR PUSTAKA}

Arikunto, Suharsimi. 2006. Dasar-Dasar Evaluasi Pendidikan. Jakarta: Bumi Aksara.

Dimyati dan Mudjiono. 2006. Belajar Dan Pembelajaran. Jakarta: PT. Rineka Cipta.
Ghozali, Imam. 2012. Aplikasi Analisis Multivariate Dengan Program IBM SPSS. Yogyakarta: Universitas Diponegoro.

Santrock, John W. 2007. Psikologi Pendidikan. Jakarta: Kencana Prenada Media Group.

Slameto. 2003. Belajar Dan Faktor-Faktor Yang Mempengaruhinya. Jakarta: PT. Rineka Cipta.

Slavin, Robert E. 2009. Cooperative Learning (Teori, Riset,Praktik). Bandung: Nusa Media.

Sudjana dan Ibrahim. 2004. Penelitian Dan Penilaian Pendidikan. Bandung: Sinar Baru Algesindo.

Sugiyono. 2010. Metode Penelitian Pendidikan. Bandung: Alfabeta.

Tirtarahardja, Umar \& La Sulo. 2005. Pengantar Pendidikan. Jakarta: PT. Rineka Cipta. 